\title{
Controlled-release Fertilizer in Cordyline spectabilis Seedlings Production, a Potential Species of the Asparagaceae Family
}

\author{
Daniele Cristina Pereira de $\operatorname{Matos}^{1}$ (1) \\ Francival Cardoso Felix ${ }^{1}$ (D) \\ Mônica Moreno Gabira ${ }^{1}$ (]) \\ Natália Saudade de Aguiar ${ }^{1}$ (B) \\ Letícia Siqueira Walter ${ }^{1}$ \\ Alexandre Dal Forno Mastella ${ }^{1}$ (it) \\ Dagma Kratz ${ }^{1}$
}

\begin{abstract}
The success of seedlings establishment for commercial planting and forest restoration depends on the availability of nutrients during seedlings production. The objective was to evaluate the efficiency in controlled-release fertilizer use in Cordyline spectabilis seedlings production and what is the additional cost per seedling produced. Seedling production was performed with doses of 0.0 (control); $2.5 ; 5.0 ; 7.5 ; 10.0$ and $12.5 \mathrm{~kg} \mathrm{~m}^{-3}$ of Basacote Plus $9 \mathrm{M}(16-08-12)$ controlled-release fertilizer added to the substrate. The experiment was placed in a greenhouse and we evaluated morphological parameters to determine seedlings growth. The dose of $10.7 \mathrm{~kg} \mathrm{~m}^{-3}$ provided a greater number of leaves (11.4) and leaf length $(24.9 \mathrm{~cm})$, higher values of shoot $(4.64 \mathrm{~g})$, root $(2.32 \mathrm{~g})$ and shoot root ratio (1.99) were obtained above $10.7 \mathrm{~kg} \mathrm{~m}^{-3}$ fertilizer. We recommend the use of $10.7 \mathrm{~kg} \mathrm{~m}^{-3}$ controlled-release fertilizer for seedlings production with an increase of $\mathrm{R} \$ 0.05$ per seedling produced.
\end{abstract}

Keywords: fertilization, forest species, morphological aspects, seedling growth, uvarana.

\section{INTRODUCTION AND OBJECTIVES}

Cordyline spectabilis Kunth \& Bouché (Asparagaceae) is known as uvarana, a native arborescent species present in primary and secondary formations of Floresta Estacional and Floresta Ombrófila Mista of Southern Brazil. It is also an important species in studies concerning regeneration, conservation, floristics, and structure of forest communities (Carvalho et al., 2016; Higuchi et al., 2016; Oliva, et al., 2018). As a climax species, Cordyline spectabilis is exigent of light, occurring in old clearings and in forests with initial canopy closure (Carvalho et al., 2016), which can contribute to forest restoration, recovery of degraded areas and enrichment of legal reserves.

The species has applications in food and medicinal industries. The palm heart canning has a high protein content and its flour has a high fiber content, both of which have a low caloric value (Helm et al., 2011). The species biomedical applications are promising as an anti-inflammatory, analgesic, rheumatism treatment, and associated diseases (Ribeiro et al., 2014). Another use of Cordyline spectabilis is in urban landscaping (Viezzer et al., 2018), which justifies its cultivation on a commercial scale.

The success of a forest plantation for commercial production or restoration purposes depends on seedling quality. Highquality seedlings enable rapid establishment with low mortality rates (Riikonen \& Luoranen, 2018). Morphological parameters can be indicators of seedling quality, such as diameter, height, shoot and root dry weight, and shoot root ratio (Grossnickle \& MacDonald, 2018a; 2018b).

Seedlings must be exposed to favorable environmental conditions during nursery production (light, substrate, water disponible and nutrients) to achieve desired quality standards. In this phase, the substrate has a supporting and nourishing function (Dalanhol et al., 2016); however, the substrate will not be able to provide all required nutrients seedling growth, making necessary the use of fertilizers (Berti et al., 2017).

${ }^{1}$ Universidade Federal do Paraná (UFPR), Departamento de Ciências Florestais, Curitiba, PR, Brasil 
The inadequate supply of essential elements results in metabolic disorders, which manifests in different ways (symptoms). Such disorders are related to element roles in the normal functioning of plants (Taiz \& Zeiger, 2017). Plants nutrient deficiency can be reversed with the use of chemical fertilizers. Controlled-release fertilizers facilitate nutrient management in seedlings production. Nutrient controlled-release keeps the levels of essential elements constant during the plant growth period, favoring growth in height, leaf area, and root system (Navroski et al., 2016).

Native forest species have different nutritional requirements. However, there is not only one specific recommendation for each species since most recommendations are based on commercial species requirements (Berti et al., 2017). Therefore, given the species potential and the need for studies aimed at seedlings production, the objective was to evaluate the efficiency in controlled-release fertilizer use in Cordyline spectabilis seedlings production and what is the additional cost per seedling produced.

\section{MATERIALS AND METHODS}

Cordyline spectabilis seedlings were donated by Chauá Society ${ }^{\circledast}$ (Campo Largo, Paraná, Brazil), produced from seeds collected from 10 marked parent trees in areas of species natural occurrence. We carried the experiment between November 2019 and April 2020, in the nursery of Departamento de Ciências Florestais, Universidade Federal do Paraná, located in Curitiba, Paraná, Brazil (25 27'02" South and $49^{\circ} 14^{\prime} 15^{\prime \prime}$ West). The region's climate is Cfb (humid subtropical with mild summer) according to the Köppen classification (Alvares et al., 2013).

The production of Cordyline spectabilis seedlings was carried out with doses: 0.0 (control); $2.5 ; 5.0 ; 7.5 ; 10.0$ and $12.5 \mathrm{~kg} \mathrm{~m}^{-3}$ Basacote $^{\circledR}$ Plus 9M (16-08-12) controlled-release fertilizer, added to the commercial substrate based on decomposed Pinus bark (Table 1). The containers used were polypropylene tubes $\left(110 \mathrm{~cm}^{3}\right)$ distributed in a completely randomized design, with five replications of 15 plants per treatment. Seedlings were kept in a greenhouse with plastic cover, with four daily irrigations of 10-20 min (micro-sprinkler $114 \mathrm{~L} \mathrm{~h}^{-1}$ ) for 144 days.

We evaluated: (a) percentage of seedling survival; (b) the number of leaves per plant; (c) leaf length with a millimeter rule; (d) shoot dry weight; (e) root system dry weight; and (f) shoot root dry weight ratio. Five plants from each replication were sampled for dry weight analysis. We washed the roots in running water to remove the remaining substrate and sectioned the plants (shoots and roots). Plant parts were placed in paper packaging and dried in a forced-air circulation oven $\left(65^{\circ} \mathrm{C} / 96 \mathrm{~h}\right)$. The samples were weighed $(0.001 \mathrm{~g})$ and result expressed in grams $(\mathrm{g})$.

Table 1. Chemical and physical characteristics of controlled-release fertilizer (Basacote ${ }^{\circledR}$ ) components and substrate used in Cordyline spectabilis seedlings production.

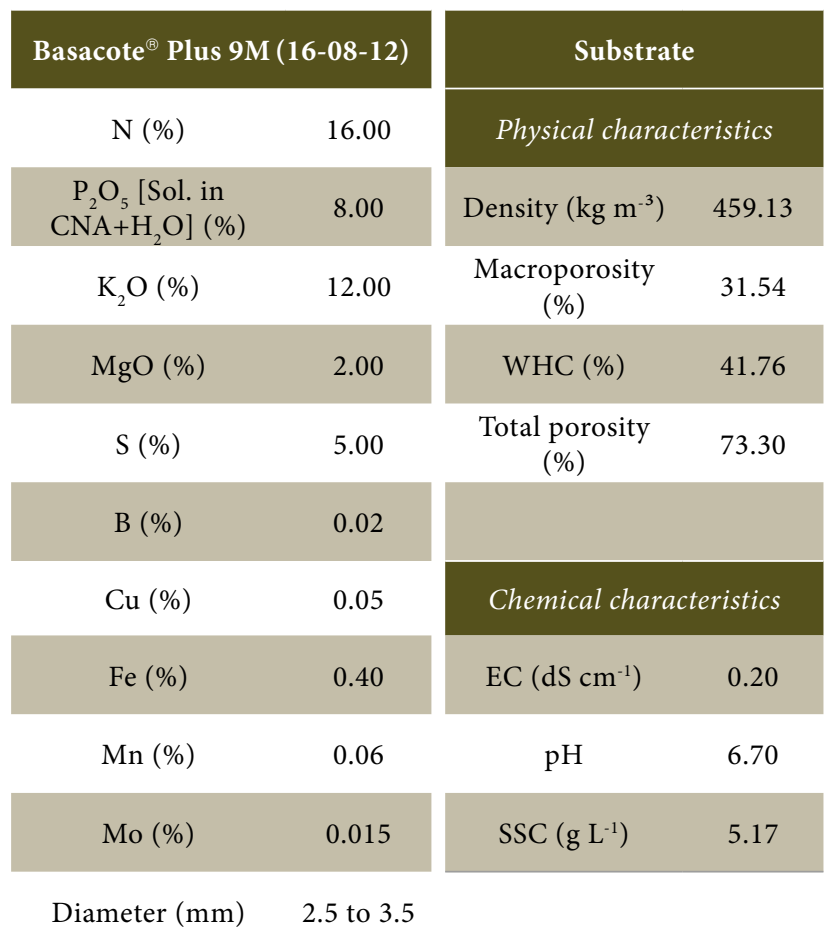

WHC: Water holding capacity; EC: electrical conductivity; SSC: Soluble salts content.

The data were submitted the normality test (ShapiroWilk) and homogeneity of variances test (Bartlett). Given these assumptions, we used regression analysis of variance by adopting equations with higher determination coefficients $\left(\mathrm{R}^{2}\right)$ to calculate the maximum technical efficiency dose for linear and polynomial equations. The statistical program used was BioEstat $^{\circledast}$ (version 5.3) (Ayres et al., 2007). In addition, we estimated the cost increase of Cordyline spectabilis seedlings production, considering the maximum technical efficiency dose and mortality rate.

\section{RESULTS AND DISCUSSION}

Cordyline spectabilis seedlings had 1 to 3 leaves ( $<3 \mathrm{~cm}$ length) and 0.10 and $0.02 \mathrm{~g}$ of shoot and root dry weight per seedling at the time of prick out (day 0 ). The six parameters evaluated were significantly influenced by the application of fertilizer (Table 2). It was possible to define the best equation in regression models for each variable, considering the controlled-release fertilizer doses. 
Table 2. Analysis of variance for production parameters of Cordyline spectabilis seedlings produced with different doses of controlled-release fertilizer Basacote ${ }^{\circledR}$ Plus 9M (16-08-12).

\begin{tabular}{|c|c|c|c|c|}
\hline Parameters & DF & MS & $\mathbf{F}$ & CV (\%) \\
\hline Seedling survival & 5 & 897.601 & $10.250^{* *}$ & 11.10 \\
\hline $\begin{array}{l}\text { Number of leaves per } \\
\text { plant }\end{array}$ & 5 & 20.525 & $23.266^{* *}$ & 9.94 \\
\hline Leaf length & 5 & 158.584 & $47.296^{* *}$ & 9.51 \\
\hline Shoot dry weight & 5 & 64.267 & $209.91^{* *}$ & 12.13 \\
\hline Root dry weight & 5 & 1.165 & $10.417^{* *}$ & 11.73 \\
\hline $\begin{array}{l}\text { Shoot root dry weight } \\
\text { ratio }\end{array}$ & 5 & 3.007 & $24.354^{* *}$ & 13.04 \\
\hline Error & 24 & & & \\
\hline Total & 29 & & & \\
\hline
\end{tabular}

DF: Degrees of freedom; MS: Mean square; F: Fisher distribution; CV: coefficient of variation.

"* significant at $1 \%$ probability level.

The survival of Cordyline spectabilis seedlings decreased as the controlled-release fertilizer dose increased, with a greater seedling survival (92\%) in control treatment $\left(0.0 \mathrm{~kg} \mathrm{~m}^{-3}\right)$ compared to $12.5 \mathrm{~kg} \mathrm{~m}^{-3}$ dose (76\%) (Figure 1A). The number of leaves per plant and leaf length showed a maximum technical efficiency dose of $10.7 \mathrm{~kg} \mathrm{~m}^{-3}$ with the adjustment of quadratic models. This dose provided a greater number of leaves (11.4) and leaf length $(24.9 \mathrm{~cm})$ of Cordyline spectabilis seedlings (Figures $1 \mathrm{~B}$ and 1C). We obtained the highest values of shoot (4.64 g), root (2.32 g), and shoot root dry weight ratio (1.99) with $12.5 \mathrm{~kg} \mathrm{~m}^{-3}$ of controlled-release fertilizer. Comparing those values with control treatment ( $0.36 \mathrm{~g}$ shoot, $0.24 \mathrm{~g}$ root and 1.06 shoot root dry weight ratio) (Figures 1D, 1E and 1F), there were increases of 1288, 966 and $188 \%$, respectively.

Differences in size and number of leaves occur because, during seedlings growing, these parts can be considered drains or sources. Young growing leaves are very strong drains of assimilates and nutrients because they import more than they export, and become a source as they expand (Simioni et al., 2014). Tiller nutritional independence occurs with its development, which coincides with the establishment of the root system (Klepper et al., 1984). Therefore, nutrients availability during this phase of seedlings production provides a greater response in growth and number of leaves.
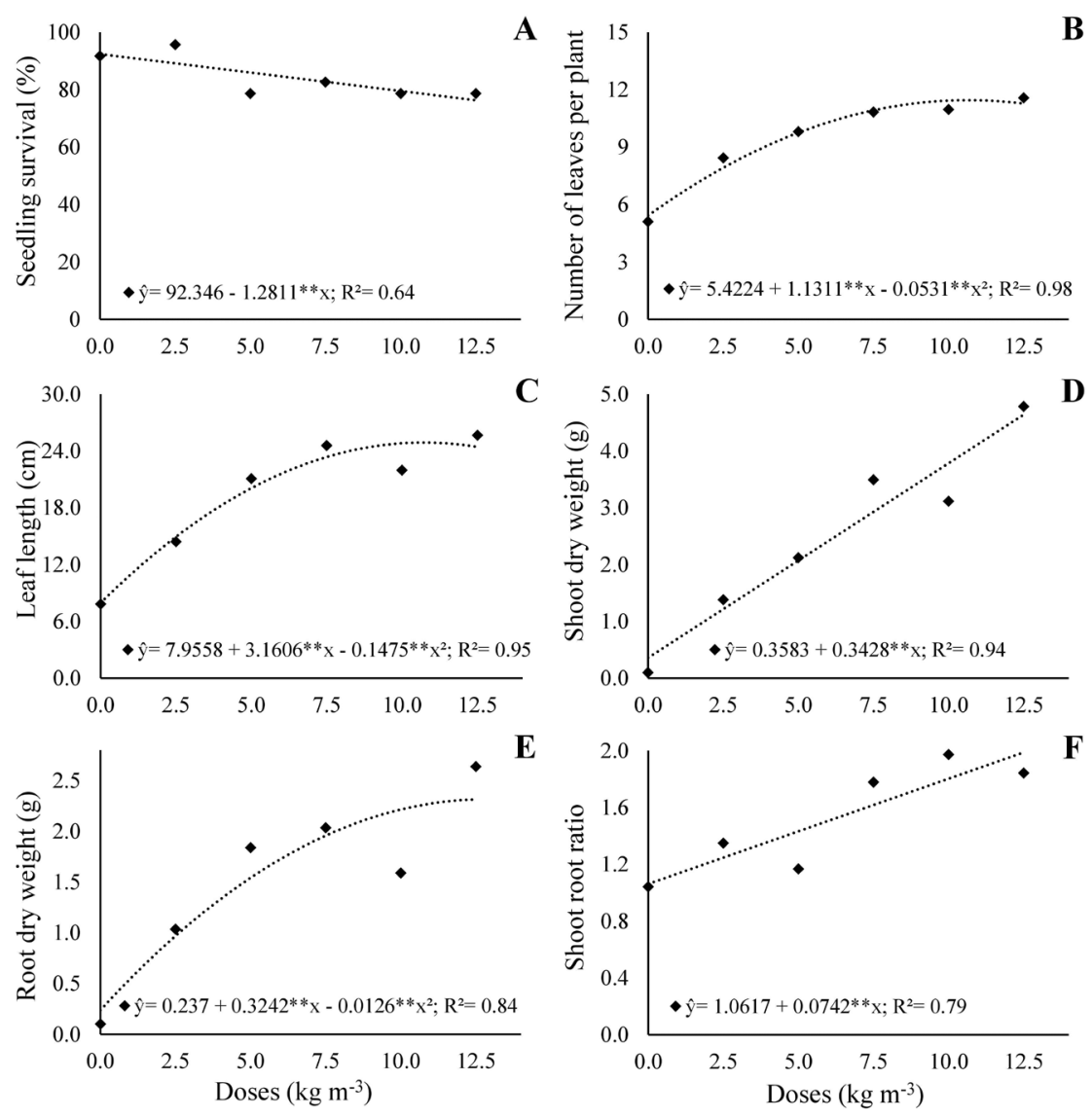

Figure 1. Parameters evaluated for Cordyline spectabilis seedlings produced in different doses of controlled-release fertilizer Basacote ${ }^{\circledR}$ Plus 9M (16-08-12). 
Applying controlled-release fertilizer favors seedlings growth in height and diameter, increasing leaf area and root system (Navroski et al., 2016). The main symptoms of nutrient deficiency in plants manifest in leaves: (i) nitrogen $(\mathrm{N})$ deficiency causes a marked loss of plant vigor due to decrease in shoot growth and formation of new leaves; (ii) potassium (K) prolonged deprivation inhibits bud formation and growth; (iii) and phosphorus ( $\mathrm{P}$ ) deficiency compromises leaf expansion (Kerbauy, 2008). Therefore, the application of these macronutrients is essential to obtain quality seedlings.

Nutrient absorption can be controlled by shoot in two paths: shoot increases nutrient absorption by growing tissues and molecules (proteins, enzymes, and chlorophylls) or provides to phloem with carbohydrates, which is used in breathing and production the ATP necessary for nutrients absorption (Costa, 2014). The largest investment in shoot dry weight is considered a strategy of Cordyline spectabilis seedlings to increase nutrient assimilation (Figure 1D). In addition, if the rhizosphere receives plenty of water and nutrients, a small root system can meet plant nutritional needs (Taiz \& Zeiger, 2017).
The higher vegetative growth of shoot allows greater competitive capacity in forest environments, which is expressed by the length and number of leaves per plant $\left(10.7 \mathrm{~kg} \mathrm{~m}^{-3}\right)$. The best result for shoot and root dry weight (above $10.7 \mathrm{~kg} \mathrm{~m}^{-3}$ ) suggests that plants have a better chance of survival and growth in the field. Also, leaves are the main source of nutrients and photoassimilate that will serve as a supply of water and nutrients to roots in the first months after planting (Dutra et al., 2015). A greater relationship between shoot and root system favors the overcoming weed competition, and better-developed roots reduce water loss in periods of drought.

We obtained higher quality of Cordyline spectabilis seedlings with the use of $10.7 \mathrm{~kg} \mathrm{~m}^{-3}$ controlled-release fertilizer with $21 \%$ mortality. The visual aspect of seedlings produced with $10.0 \mathrm{~kg} \mathrm{~m}^{-3}$ confirms our results (Figure 2); seedlings have a developed root and shoot system, healthy appearance, green color in the leaves, excellent aggregation of the roots to the substrate and presence of secondary roots. These results indicate high quality of seedlings (Grossnickle \& MacDonald, 2018a; 2018b).

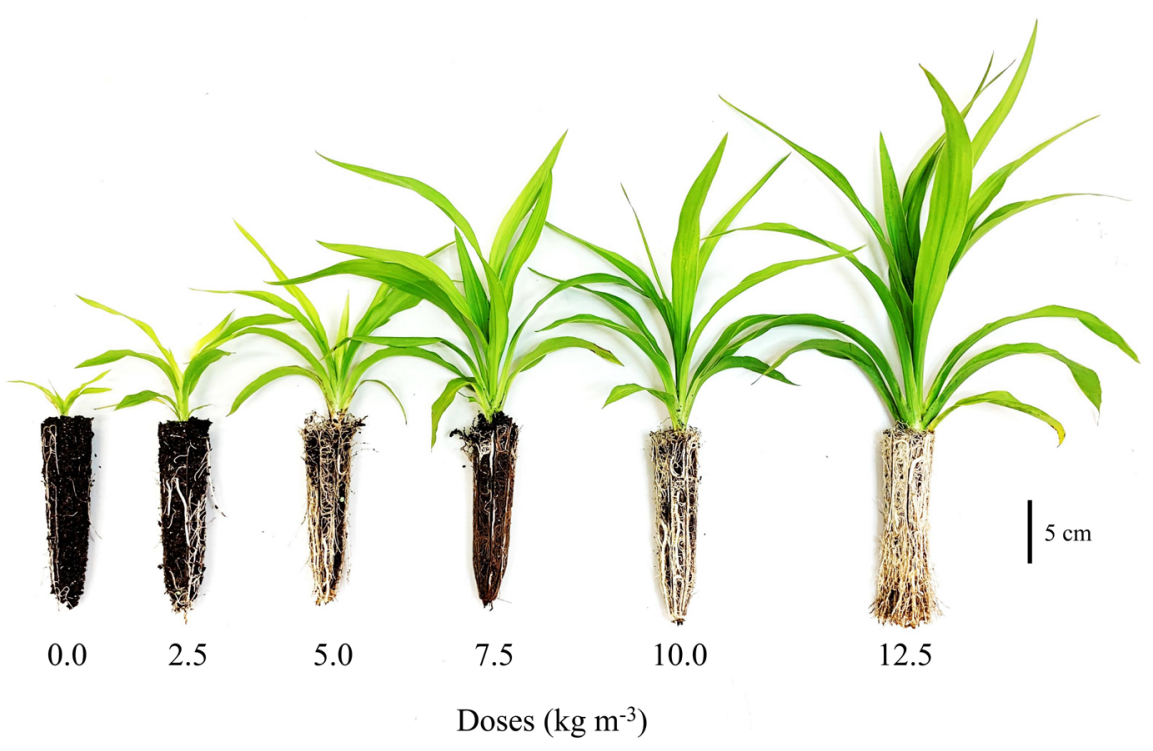

Figure 2. Morphological aspect of Cordyline spectabilis seedlings produced in different doses of controlled-release fertilizer Basacote ${ }^{\circledR}$ Plus 9M (16-08-12).

Despite superior results of shoot (4.64 g), root (2.32 g) and shoot root dry weight ratio (1.99) of Cordyline spectabilis seedlings produced with $12.5 \mathrm{~kg} \mathrm{~m}^{-3}$ controlled-release fertilizer (Figures 1D, 1E and 1F), it was difficult to remove the containers. The presence of entangled roots also indicates possible problems for field establishment. Comparatively, seedlings produced with doses lower than $7.5 \mathrm{~kg} \mathrm{~m}^{-3}$ of fertilizer have poorly developed roots and shoots and a stunted aspect (Figure 2), which impairs field establishment.
The production costs of Cordyline spectabilis seedlings with $10.7 \mathrm{~kg} \mathrm{~m}^{-3}$ results in an additional cost of $\mathrm{R} \$ 374.50$ per $\mathrm{m}^{3}$ substrate or $\mathrm{R} \$ 0.04$ per seedling produced in a tube $\left(110 \mathrm{~cm}^{3}\right)$ (Figure 3). For this value, we considered only the variation of controlled-release fertilizer Basacote ${ }^{\circledR}$ Plus $9 \mathrm{M}$ (16-08-12), which is sold at an average price of $R \$ 35.00$ per kilogram in 2020 . When we add seedling mortality rate during the production process (Figure 1A), the maximum value-added per Cordyline spectabilis seedling was $\mathrm{R} \$ 0.05$, which is better than production in $7.5 \mathrm{~kg} \mathrm{~m}^{-3}(\mathrm{R} \$ 0.03)$ and less than $12.5 \mathrm{~kg} \mathrm{~m}^{-3}(\mathrm{R} \$ 0.06)$ (Figure 3$)$. 


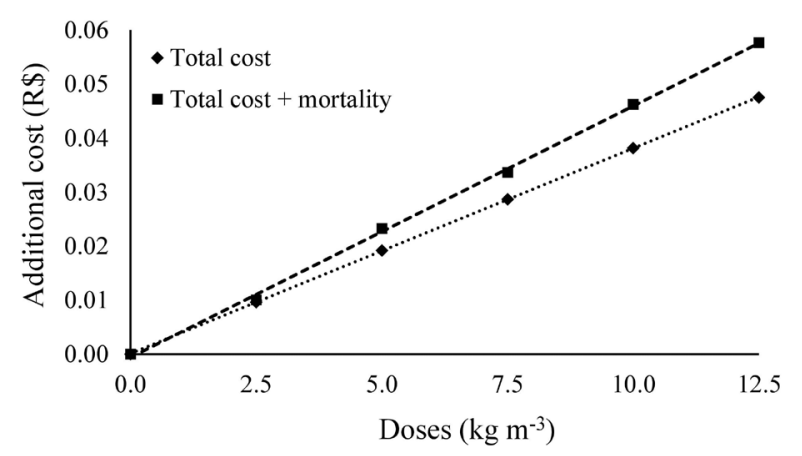

Figure 3. Additional cost per seedling of Cordyline spectabilis produced in different doses of controlled-release fertilizer Basacote ${ }^{\circledR}$ Plus 9M (16-08-12).

\section{CONCLUSIONS}

The application of controlled-release fertilizer Basacote ${ }^{\circledast}$ Plus 9M (16-08-12) favors the growth of Cordyline spectabilis seedlings. We recommend the use of $10.7 \mathrm{~kg} \mathrm{~m}^{-3}$ for the production of this species seedlings with a maximum increase of $\mathrm{R} \$ 0.05$ per seedling produced.

\section{ACKNOWLEDGEMENTS}

The present study was performed with the support of the Coordenação de Aperfeiçoamento de Pessoal de Nível Superior Brazil (CAPES) - Finance Code 001, and the Conselho Nacional de Desenvolvimento Científico e Tecnológico (CNPq).

To the Chauá Society and Rohrbacher. Florestal Ltda. for supplying the inputs used in this research.

\section{SUBMISSION STATUS}

Received: 25 Jun. 2020

Accepted: 15 Jan. 2021

Associate editor: Eduardo Vinicius Silva

\section{CORRESPONDENCE TO}

\section{Francival Cardoso Felix}

Universidade Federal do Paraná (UFPR), Departamento de Ciências

Florestais, Avenida Prefeito Lothário Meissner, 632, CEP: 80210-170,

Curitiba, PR, Brasil

e-mail: felixfc@outlook.com.br

\section{REFERENCES}

Alvares CA, Stape JL, Sentelhas PC, Gonçalves JLM, Gerd S. Köppen's climate classification map for Brazil. Meteorologische Zeitschrift 2013; 22(6): 711-728. 10.1127/0941-2948/2013/0507

Ayres M, Ayres Júnior M, Ayres DL, Santos AAD. BioEstat 5.0: aplicações estatísticas na área das ciências biológicas e biomédicas. 5rd ed. Belém: Instituto Mamirauá; 2007.
Berti CLF, Kamada T, Silva MP, Menezes JFS, Oliveira ACS. Growth of seedlings Dipteryx alata (Vog) on substrate enriched with nitrogen, phosphorus and potassium. Cultura Agronômica 2017; 26(2): 191-202. 10.32929/2446-8355.2017v26n2p191-202

Carvalho J, Velazco SJE, Pereira TK, Galvão F. Natural regeneration under reforestation of Araucaria angustifolia and Pinus sp. in Tunas do Paraná, PR, Brazil. Pesquisa Florestal Brasileira 2016; 36(85): 9-16. 10.4336/2016.pfb.36.85.892

Costa AR. Nutrição mineral de plantas vasculares. Portugal: Universidade de Évora; 2014.

Dalanhol SJ, Nogueira AC, Gaiad S, Kratz D. Effect of arbuscular mycorrhizal fungi and fertilization on growth of seedlings of Eugenia uniflora L., produced in different. Revista Brasileira de Fruticultura 2016; 38(1): 117-128. 10.1590/0100-2945-266/14

Dutra TR, Massad MD, Matos OS, Sarmento MFQ, Oliveira JC. Initial growth and quality of seedlings caviúna-of-savannah and caroba-of-field in response to nitrogen fertilization. Agropecuária Científica no Semiárido 2015; 11(3): 52-61. 10.30969/acsa.v11i3.647

Grossnickle SC, MacDonald JE. Why seedlings grow: influence of plant attributes. New Forests 2018a; 48:1-34. 10.1007/s11056-017-9606-4

Grossnickle SC, MacDonald JE. Seedling quality: history, application and plant attributes. Forests 2018b; 9(283): 1-23. 10.3390/f9050283

Helm C, Steenbock W, Mazza MCM, Mazza CAM. Chemical composition of canned heart of Cordyline spectabilis and the flour obtained from post-processing residue. Pesquisa Florestal Brasileira 2011; 31(67): 265-268. 10.4336/2011.pfb.31.67.265

Higuchi P, Silva AC, Ferreira TS, Souza ST, Gomes JP, Silva KM et al. Floristic and structure of the tree component and relation with environmental variables in a forest remnant in Campos Novos, SC. Ciência Florestal 2016; 26(1): 35-46. 10.5902/1980509821089

Kerbauy GB. Fisiologia vegetal. 2rd ed. Rio de Janeiro: Guanabara Koogan; 2008.

Klepper B, Belfort RK.; Rickman RW. Root and shoot development in winter wheat. Agronomy Journal 1984; 76(1): 117-122. 10.2134/ agronj1984.00021962007600010029x

Navroski MC, Nicoletti MF, Lovatel QC, Pereira MO, Tonett EL, Mazzo MV et al. Effect of the volume of the core and fertilizer rates on the growth of Eucalyptus dunnii Maiden. Revista Agrarian 2016; 9(31): 26-33.

Oliva EV, Reissmann CB, Marques R, Bianchin JE, Dalmaso CA, Winagraski E. Floristic and structure of two secondary arboreal community with different disturbance degree in recovery process. Ciência Florestal 2018; 28(3): 1088-1103. 10.5902/1980509833465

Ribeiro LG, Kerppers II, Paz IA, Rolão MPP, Oliveira TB, Eltchechem CL et al. Antinociceptive effects of saccharose and aqueous extract of Cordyline dracaenoides Kunth (uvarana) in experimental models after induction of hyperalgesia using capsaicin. Medical Express 2014; 1(2): 91-94. 10.5935/MedicalExpress.2014.02.07

Riikonen J, Luoranen J. Seedling production and the field performance of seedlings. Forests 2018; 9(740): 1-4. 10.3390/f9120740

Simioni TA, Hoffmann A, Gomes FJ, Mousquer CJ, Teixeira UHG, Fernandes GA et al. Senescence, removal, transport of nutrients and nutritional value in tropical grasses. Pubvet 2014; 8(13): 262.

Taiz L, Zeiger E. Fisiologia vegetal. 6rd ed. Porto Alegre: Artmed; 2017.

Viezzer J, Biondi D, Martini A, Grise MM. Vegetation in the landscape of Curitiba squares, Paraná State. Ciência Florestal 2018; 28(1): 369-383. 10.5902/1980509831608 